\title{
Rigour and quality: the secrets behind a scientific journal on the rise
}

\author{
Cédric Vermeulen ${ }^{(1)}$, Gilbert Berben ${ }^{(2)}$, Bernard Pochet ${ }^{(3)}$
}

(1) ULg - Gembloux Agro-Bio Tech, Laboratoire de Foresterie des régions tropicales et subtropicales, Gestion des Ressources forestières, Passage des Déportés, 2, 5030 Gembloux, Belgique.

(2) CRA-W, Département Valorisation des Productions, Bâtiment Henseval, Chaussée de Namur, 24, 5030 Gembloux, Belgique.

(3) ULg - Gembloux Agro-Bio Tech, ULiege Library, Passage des Déportés, 2, 5030 Gembloux, Belgique. E-mail: bernard. pochet@uliege.be

With the bibliometric tools now at our disposal, it is easy to regularly monitor the evolution of our articles' citation numbers. This therefore generated expectations, which were more than fulfilled when the official news came out last July: with an impact factor of 1.23 in 2018, our journal has crossed the symbolic threshold of 1 . This impact factor remains modest for a generalist journal in the field of agronomy, but nevertheless it means we rank first among bilingual (French and English) scientific journals in this field. The evolution of BASE since 1997 reflects the constant concern for quality that drives the editorial and publishing boards. The Editorial Board has recently been renewed and will soon welcome members from other Belgian universities. The rigour in the selection of articles for publication translates to a decreasing total number of published articles: the rejection rate is in the high range of 70 to $90 \%$. Moreover, the internal process for handling manuscripts is constantly evolving; for example, a new and strengthened procedure will improve the tracking of citations in journals known to be predatory. In addition, a new version of the manuscript management software, OJS, has just been put online. Finally, the switch from paper to fully digital is planned for 2020. These decisions and developments do not solve all the weaknesses identified in last year's editorial (Pochet et al., 2018'), but the significant increase in the number of citations shows that BASE is on the right track to affirm its position as an international and bilingual scientific journal in the field of activities it covers. Lastly, we take the opportunity of this editorial to thank our main sponsors, the National Fund for Scientific Research (FNRS), the Walloon Public Service, Gembloux Agro-bio Tech, and the Walloon Agricultural Research Centre.

\section{Rigueur et qualité : les secrets d'une revue scientifique en pleine croissance}

Avec les outils bibliométriques dont nous disposons, il est aisé de suivre régulièrement l'évolution du nombre de citations de nos articles. La nouvelle officielle, attendue mais néanmoins bienvenue, est tombée en juillet dernier : avec un facteur d'impact de 1,23 pour 2018, la revue a dépassé le cap symbolique de 1. Ce facteur d'impact reste modeste pour une revue généraliste dans le domaine de l'agronomie au sens le plus large, mais la place néanmoins en première position parmi les revues scientifiques bilingues français-anglais du domaine. L'évolution de BASE, depuis 1997, reflète le souci constant de qualité qui anime les comités de rédaction et d'édition. Le Comité de Rédaction a été récemment renouvelé et sera bientôt élargi à d'autres universités belges. La rigueur dans la sélection des articles publiés se traduit par un nombre d'articles total publié en baisse, imputable à un taux de rejet situé dans une fourchette élevée, de 70 à $90 \%$. Le processus interne de traitement des manuscrits est aussi en évolution constante ; pour exemple, une procédure nouvelle et renforcée va traquer encore plus qu'auparavant la citation des revues réputées prédatrices. Par ailleurs, une nouvelle version du logiciel de gestion des manuscrits, OJS, vient d'être mise en ligne. Enfin, l'abandon de la version papier au profit d'une version entièrement numérique est prévue pour 2020. Ces décisions et évolutions ne résolvent pas toutes les faiblesses identifiées dans l'éditorial de l'année passée (Pochet et al., $2018^{1}$ ), mais la hausse importante du nombre de citations de la revue démontre que BASE se trouve sur la bonne voie pour maintenir une place honorable en tant que revue scientifique bilingue internationale dans le domaine d'activités couvert. Cet éditorial constitue également l'occasion de remercier nos principaux bailleurs que sont le Fonds National pour la Recherche Scientifique (FNRS), le Service Public de Wallonie, la Faculté de Gembloux Agro-bio Tech et le Centre wallon de Recherches Agronomiques.

\footnotetext{
${ }^{1}$ Pochet B., 2018. Developing a scientific journal in a changing world. Biotechnol. Agron. Soc. Environ., 22(4), $203-207$.
} 